\title{
EU BANK RECAPITALISATION AND THE BAIL-IN OPTION: AN ANALYSIS OF THE EFFECTS OF MANDATORY BAIL-IN ON CREDITORS' PROPERTY RIGHTS
}

\author{
Tracy Chiyedza Maguze*
}

\begin{abstract}
As of 1 January 2016, all members of the European Union (EU) are required to have bail-in provisions as part of their national bank resolution and recapitalisation legislation. The bail-in of bank creditors' claims in order to recapitalise the bank is not a new phenomenon, it was utilised in Cyprus in 2013 and has since been used in a series of rescue operations launched for struggling banks in Austria, Slovenia, Greece, Italy, Hungary, Denmark, and Portugal. One of the most obvious concerns with the bail-in tool is that it deprives bank creditors of their property, namely a right to claim repayment of a debt obligation. The object of this paper is to determine if bail-in rules actually interfere with the right to property of bank creditors and whether such interference is unjustified. The paper concludes that, firstly, bail-in amounts to an interference with peaceful enjoyment of property and, secondly, such interference cannot be justified because bail-in rules fall short of the legality and legitimacy requirements which must be met when the State interferes with the right to property. Bail-in rules infringe bank creditors' right to property and, as such, present a legal risk to resolution authorities in Member States.
\end{abstract}

\section{A. INTRODUCTION}

Since 1 January 2016, all members of the European Union (EU) are required to have bail-in provisions as part of their national bank resolution and recapitalisation legislation. Bank resolution and recapitalisation in the EU is guided by the Bank Resolution and Recovery Directive (BRRD). ${ }^{1}$ The legislation provides a common framework for the recovery and resolution of troubled banks across the $28 \mathrm{EU}$ countries. The regime aims to eliminate moral hazard, minimise taxpayers' exposure to losses in bank insolvency, and ensure stability in the financial markets. ${ }^{2}$ The BRRD empowers public authorities to take a failing bank into receivership, transfer the healthy parts of the business to another entity and wind down the rest or transfer losses to shareholders and creditors of the bank.

\footnotetext{
* PhD Candidate and FCT Scholar, Católica Global School of Law, Universidade Católica Portuguesa. I am grateful to Dr Parker Hood for guidance provided during the writing of the LLM dissertation on which this paper is based. Any errors remain my own. Special thanks also goes to the Fundação para a Ciência e a Tecnologia.

${ }^{1}$ Directive 2014/59/EU of the European Parliament and of the Council of 15 May 2014 establishing a framework for the recovery and resolution of credit institutions and investment firms and amending Council Directive 82/891/EEC, and Directives 2001/24/EC, 2002/47/EC, 2004/25/EC, 2005/56/EC, 2007/36/EC, 2011/35/EU, 2012/30/EU and 2013/36/EU, and Regulations (EU) No 1093/2010 and (EU) No 648/2012, of the European Parliament and of the Council OJ 2014 L173/190 (BRRD).

2 ibid. The BRRD is similar to the framework established in the US, in 2010, under the Title II of the Dodd-Frank Wall Street Reform and Consumer Protection Act of 2010.
} 


\section{Bail-In on Creditors' Property Rights}

Bail-in is not a new phenomenon. It was used in Cyprus in 2013 when bank account holders had their uninsured deposits converted to equity in order to recapitalise the country's biggest bank, Bank of Cyprus, after it suffered massive losses from its exposure to debt-ridden Greece. The Central Bank of Cyprus, acting as the resolution authority, converted 37.5 percent of deposits exceeding $€ 100,000$ into equity. In essence, Cypriot depositors were compelled to foot the bill for rescuing the bank, as opposed to the burden being shifted to taxpayers, through bail-out, as had happen in other European countries at the onset of the financial crisis. Since Cyprus, bail-in has been used in a series of rescue operations launched for struggling banks in Austria, Slovenia, Greece, Italy, Hungary, Denmark, and Portugal. ${ }^{3}$ One of the most obvious concerns with the use of the bail-in tool is that it deprives bank creditors of their property, namely a right to claim repayment of a debt obligation. Indeed, in all the countries noted above, the implementation of bail-in has been followed by outrage from creditors and litigation instituted by disgruntled investors, whose claims against banks have either been written down or converted to equity, challenging the legality and legitimacy of the actions of resolution authorities.

The object of this paper is to determine if bail-in rules actually interfere with the right to property of the holders of eligible liabilities and whether such interference is unjustified. The second section of this paper provides a background for the adoption of bail-in rules in the EU, while the third section provides more insight into the powers that are granted under the bail-in rules, how the bail-in tool is to be applied, and which creditors are affected and in what way. In the fourth section, the argument will be put forward that the proposed application of the bailin tool will infringe on creditors' property rights. The argument shall be furthered using the right to property enshrined in Article 1 of Protocol 1 of the European Convention of Human Rights (ECHR) and interpreted by the European Court of Human Rights (ECtHR), which allows for a more unified analysis. The experiences of four countries, namely Slovenia, Portugal, Austria, and Italy, all of which have recently experienced bail-in, shall be used to illustrate how bail-in rules fall foul of the right to property. The paper concludes firstly, bail-in amounts to an interference with peaceful enjoyment of property and secondly, such interference cannot be justified because bail-in rules fall short of the legality and legitimacy requirements which must be met when the State interferes with the right to property. Bail-in rules infringe

\footnotetext{
${ }^{3}$ European Parliament, Briefing on the Implementation of Bail-in in Recent Resolution and State Aid Cases, PE 574.395 (22 February 2016) <http://www.europarl.europa.eu/RegData/etudes/BRIE/2016/574395/IPOL_BRI_(2016)574395_EN.pdf> accessed 11 March 2016.
} 
bank creditors' right to property and, as such, present a legal risk to resolution authorities in Member States because creditors are likely to keep challenging the infringement of their right to property.

\section{B. WHAT IS BAIL-IN?}

\section{Background to the Bank Recovery and Resolution Directive (BRRD)}

During the Global Financial Crisis of 2007-2008 (GFC), the EU Member States relied on three alternatives to prevent the failure of banks in their territory considered to be Too-Big-To-Fail, (TBTF). The state would either: i) insure bank deposits; and/or ii) provide liquidity support; or iii) offer a public bailout to a failing but systemically important bank (SIB). The third method in particular ran contrary to one of the main tenets of a free market economy, which is 'owners and creditors are supposed to bear the losses of a failed venture. ${ }^{4}$ Regardless, the amount of aid offered to banks in the EU during the crisis totalled approximately 30 percent of the EU's GDP. ${ }^{5}$ Worst of all is that public intervention by governments created the notion that banks which were TBTF would always have an implicit guarantee of protection from failure, and, this in turn, created the problem of 'moral hazard' ${ }^{6}$ As a result of moral hazard, firms engage in risky investments, which generally have a higher return, because they perceive that government will provide a 'safety net', whilst the firms' creditors and counterparties also have less incentive to monitor the firms and price risk appropriately because of the belief that government will absorb all losses. ${ }^{7}$

One way of avoiding the moral hazard problem is to convince market participants that the government will not provide liquidity support or bail outs, and instead the bank will be resolved despite its systemic importance. Traditionally, states have relied on general insolvency laws to address the resolution of banks. ${ }^{8}$ Under such laws, the company's assets are sold off to pay its creditors, and in the case of banks, depositors have the extra protection of deposit insurance. ${ }^{9}$ The threat of liquidation should promote market discipline.

\footnotetext{
${ }^{4}$ Charles AE Goodhart and Emilios Avgouleas, 'A Critical Evaluation Of Bail-In As A Bank Recapitalization Mechanism' in Douglas D Evanoff, Andrew Haldane and George G Kaufman (eds), The New International Financial System: Analyzing the Cumulative Impact of Regulatory Reform (World Scientific Publishing 2016).

${ }^{5}$ Commission, 'An EU Framework for Crisis Management in the Financial Sector' COM (2010) 0579 final (Comment on a Framework for Crisis Management).

6 ibid.

${ }^{7}$ Comment on a Framework for Crisis Management (n 5).

${ }^{8}$ Barbra J Attinger, 'Crisis Management and Bank Resolution: Quo Vadis, Europe?' (2011) ECB Legal Working Paper No 13, 2 < https://www.ecb.europa.eu/pub/pdf/scplps/ecblwp13.pdf > accessed 5 July 2014.

9 ibid 8.
} 
The failure of high profile banks in the EU, which occurred during the GFC, showed, however, that market discipline was not sufficient to counter moral hazard. This is because the dispersed nature of banks' unsecured creditors prevents them from forming a coherent monitoring force. In any case, most depositors lack the sophistication or the means to closely monitor the complex business activities of banks. ${ }^{10}$ Furthermore, general insolvency laws proved inadequate for resolving financial institutions because they lacked the required speed of intervention, continuation of critical functions and preservation of stability. ${ }^{11}$ Given that traditional insolvency laws could not be used to resolve domestic banks, it was hardly surprising that the same regimes were unsuitable in the face of failing cross-border banks. The difficulties surrounding the resolution of a domestic bank became magnified when applied to a bank operating on a cross-border basis. This is because there was no harmonisation of the procedures for resolving institutions at European Union level. Each Member State applied its own insolvency laws and these varied considerably from state to state. ${ }^{12}$ In the aftermath of the GFC it was clear, therefore, that there was need for special resolution regimes for banks at a national level, as well as a regime that allowed for the coordinated resolution of financial institutions operating multiple legal entities in multiple jurisdictions.

In response to the threat caused by failing banks, the European Parliament issued the BRRD. The aim of the Directive is to avoid the destabilisation of the financial markets and minimise costs for taxpayers. ${ }^{13}$ This will be achieved by granting public administrative authorities, ${ }^{14}$ who are independent from economic actors, powers to maintain uninterrupted access to deposits and payment transactions, sell viable portions of the business and apportion losses in a manner that is fair and predictable. ${ }^{15}$ The recovery and resolution regime applies to credit institutions, investment firms, insurance undertakings, and financial holding companies. ${ }^{16}$

The BRRD proposes a two phased approach. First, the implementation of early intervention measures designed to prevent bank failures, and, secondly, where failure is unavoidable, the orderly resolution of banks. ${ }^{17}$ It provides for timely entry into the resolution

\footnotetext{
10 Vanessa Le Lesle, 'Bank Debt in Europe: Are Funding Models Broken?' (2012) IMF WP/12/299 <http://www.imf.org/external/pubs/ft/wp/2012/wp12299.pdf> accessed 5 July 2014.

${ }^{11}$ BRRD, Preamble (4).

12 ibid.

13 BRRD, art 31.

${ }^{14}$ BRRD, art 3(2).

15 BRRD, art 31.

${ }^{16}$ BRRD, art 1(1).

17 Commission, 'EU Bank Recovery and Resolution Directive (BRRD): Frequently Asked Questions' Memo (2014) 297.
} 
before a financial institution's balance sheet becomes insolvent and before all equity is wiped out, that is before it fails. ${ }^{18} \mathrm{~A}$ bank would be considered to be failing where it infringes, or is close to infringing, its registration requirements; its assets are less than its liabilities; it is unable to pay its debts as and when they fall due; and/or if it requires extraordinary public support. ${ }^{19}$ Where a bank has failed, the resolution authorities will be armed with four tools which they may use individually or in combination, to resolve the institution: a) the sale of business tool; b) the bridge institution tool; c) the asset separation tool; and d) the bail-in tool. ${ }^{20}$

The resolution process will be funded through national resolution funds, set up ex ante, in each Member State. Financial firms subject to the resolution regimes will be required to make contributions, over a period of 10 years, of at least 1 percent of their covered deposits.

\section{The Bail-in Tool}

The most controversial tool is the bail-in tool. Bail-in is a statutory power to restructure the balance sheet of a distressed bank by converting and/or writing down its liabilities to equity. ${ }^{21}$ The aim of the bail-in tool is to counter the problem of moral hazard, by removing the safety net provided by taxpayers. ${ }^{22}$ Bail-in takes away the implicit too-big-to fail subsidy and the effect of this is two-fold. Firstly, it compels investors to closely monitor the risk -taking activities of banks, thus introducing market discipline, and, secondly investors will price risk more accurately, which in turn promotes a more efficient allocation of funds. ${ }^{23}$ Should the bank face crisis, then the costs of recovery will be borne by the bank's shareholders and creditors. Bail-in is carried out on a going concern basis, which means that the bank continues to operate and provide essential services to its customers while it is being recapitalised. ${ }^{24}$ This will help to limit disruption and maintain public confidence in the banking system.

Banks will therefore, be required to hold a minimum requirement of own funds and eligible liabilities (MREL), capable of being bailed in, which is calculated as a percentage of the total liabilities and own funds of the institution. ${ }^{25}$ On 3 July 2015, the European Banking

\footnotetext{
18 ibid.

${ }^{19}$ BRRD, art 32 (4).

${ }^{20}$ BRRD, art 39.

${ }^{21}$ Jianping Zhou and others, 'From Bail-out to Bail-in: Mandatory Debt Restructuring of Systemic Financial Institutions' (2012) IMF Staff Discussion Note 12/03, 6

<https://www.imf.org/external/pubs/ft/sdn/2012/sdn1203.pdf > accessed 10 June 2014.

${ }^{22}$ Commission, 'Bank Recovery and Resolution Proposal: Frequently Asked Questions' Memo (2012) 416 (Memo on Bank Recovery and Resolution).

${ }^{23}$ Benoît Cœuré, 'The implications of bail-in rules for bank activity and stability' (Opening Speech at ECB Conference on 'Financing the recovery after the crisis- the roles of bank profitability, stability and regulation', Milan, 30 September, <http://www.ecb.europa.eu/press/key/date/2013/html/sp130930.en.html > accessed 5 June 2014.

${ }^{24}$ Zhou and others (n 21) 6.

${ }^{25}$ BRRD, art 45(1).
} 


\section{Bail-In on Creditors' Property Rights}

Authority, (EBA), published the final Draft Regulatory Technical Standard, (RTS), outlining the criteria to be used by national regulators to determine the MREL. Articles 1 to 5 of the RTS contains five criteria to be used in determination procedures, namely:

i. The amount necessary to ensure loss absorption;

ii. The amount necessary to continue to comply with conditions for authorisation and to carry out activities and sustain market confidence in the institution;

iii. Exclusions from bail-in or partial transfer which are an impediment to resolvability;

iv. Business model, funding model and risk profile of the struggling bank; and

v. Size and systemic risk of the bank. ${ }^{26}$

In terms of the BRRD, Article 44(1), the bail-in tool, may be applied to all the liabilities of a bank with the exception of:

a) Guaranteed deposits

b) Secured liabilities

c) Client assets or money held by the bank

d) Trust funds

e) Interbank liabilities with a maturity of seven days

f) Liabilities to payment systems

g) Liabilities to employees, trade creditors, tax and social security authorities and deposit guarantee schemes. ${ }^{27}$

In essence, all unsecured liabilities and liabilities in excess of any security provided shall be eligible for bail-in, although the resolution authority may exclude an eligible liability under certain circumstances. ${ }^{28}$ Resolution authorities would be able to compensate for the discretionary exclusion through funds from the resolution fund. Shareholders and creditors, however, must bear a minimum of 8 percent of losses before the resolution authority considers contributions from the resolution fund towards recapitalising the bank. ${ }^{29}$ And even then, such contribution shall not exceed 5 percent of the total liabilities. ${ }^{30}$

The bail-in measures propose to follow the priority of eligible liabilities under national insolvency laws. This means that after equity, first subordinated debt and then potentially

\footnotetext{
${ }^{26}$ European Banking Authority, 'Draft Regulatory Technical Standards Specifying Criteria Relating to the Methodology for Setting Minimum Requirement for Own Funds and Eligible Liabilities According to Article 45(2) of Directive 2014/59/EU' RTS (2015) 05 (Draft RTS on MREL).

27 BRRD, art 44(2)(e).

28 BRRD, art 44(3).

29 BRRD, art 44(5).

${ }^{30}$ ibid.
} 
senior debt will be bailed in. ${ }^{31}$ Deposits, both insured and uninsured, will be preferred over senior creditors. ${ }^{32}$ It is important to understand the structure of a bank balance sheet in order to understand how bail-in will function. In the most basic terms, the balance sheet consists of a bank's source of funding, ie its capital and liabilities and the uses of that funding the assets. The providers of the funding are shareholders, who provide capital, and creditors, the holders of liability such as bond holders and depositors.

These different sources of funding exist in a hierarchy, and in terms of insolvency laws when a company is liquidated, the company's assets are sold and the proceeds from the sale are distributed amongst the company's creditors according to that hierarchy. Therefore, in the event that a bank fails and has to be liquidated, senior creditors will be repaid first, then subordinated creditors, and lastly shareholders. As such, if senior creditors are unable to fully recover, then subordinated creditors and will receive nothing, while shareholders are wiped out. In a similar vein, if subordinated creditors are unable to fully recover, then the shareholders will be wiped out.

It should also be noted that there is also a hierarchy amongst the creditors (Figure 1). There is senior debt, subordinated debt, then junior debt. At the very bottom of the funding pyramid there is equity, which is divided into preferred equity, which ranks higher, and common equity. The bail-in regime will follow a hierarchy which resembles an inverted insolvency pyramid (Figure 2). First to be written down are common equity Tier One instruments, then additional Tier 1 instruments, followed by Tier 2 capital instruments, then subordinated debt, followed by senior debt. The shareholders' equity will either be cancelled or diluted as a first step in bail-in, ${ }^{33}$ then subordinated debt will be converted to equity, after which senior debt, including uncovered deposits will be converted to equity, followed by Small to Medium Enterprises, ('SME'), and individual deposits in excess of the covered amount, $€$ 100 000. Finally, the Deposit Insurance Scheme, ('DIS'), will be required to make a contribution equaling the amount of exempted deposits, while deposits in excess will be eligible for bail-in.

\footnotetext{
${ }^{31}$ BRRD, art 48(1).

${ }^{32}$ In some jurisdictions senior unsecured creditors rank parri passu with depositors.

${ }^{33}$ BRRD, art 47(1).
} 


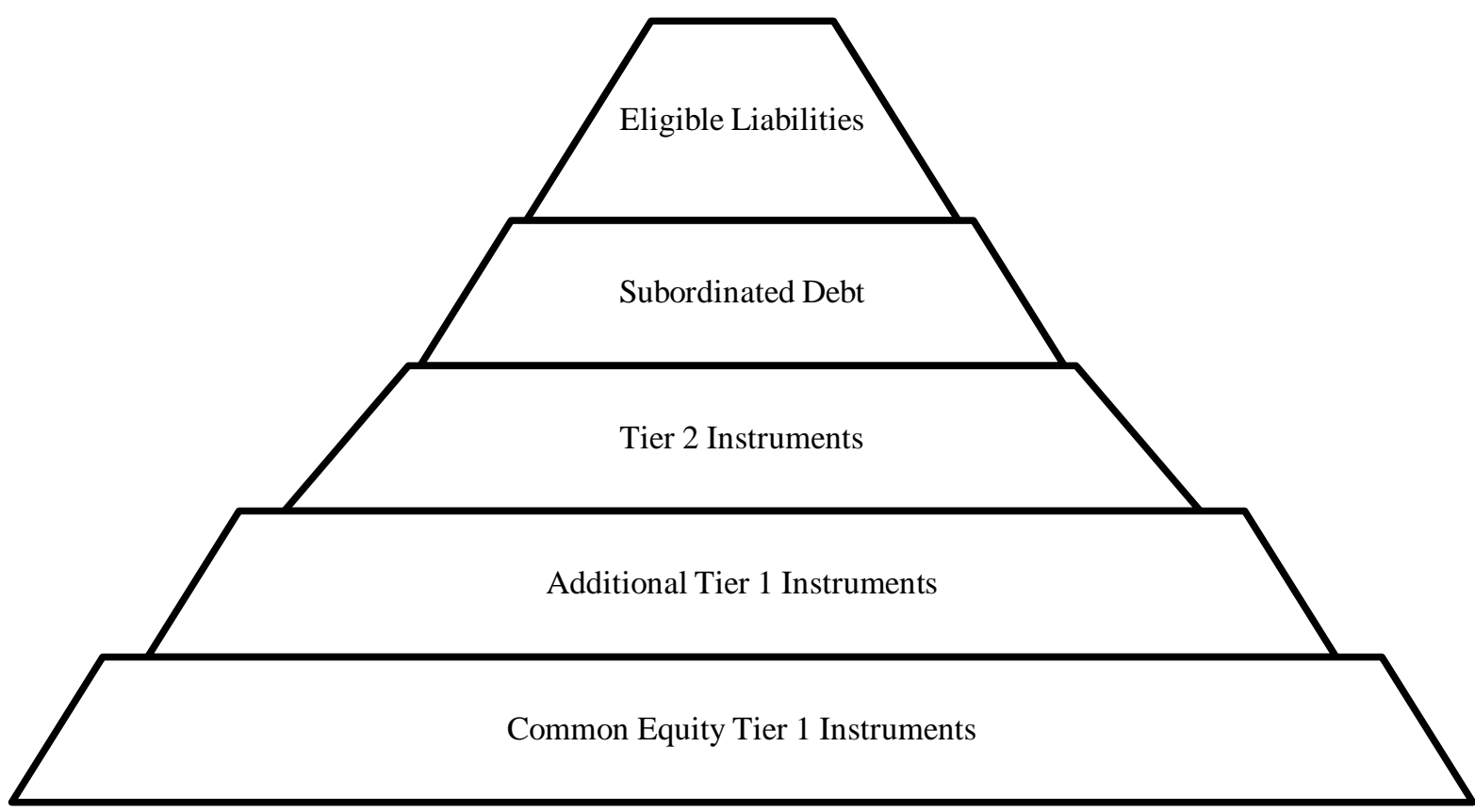

Figure 1. Hierarchy of claims under insolvency law

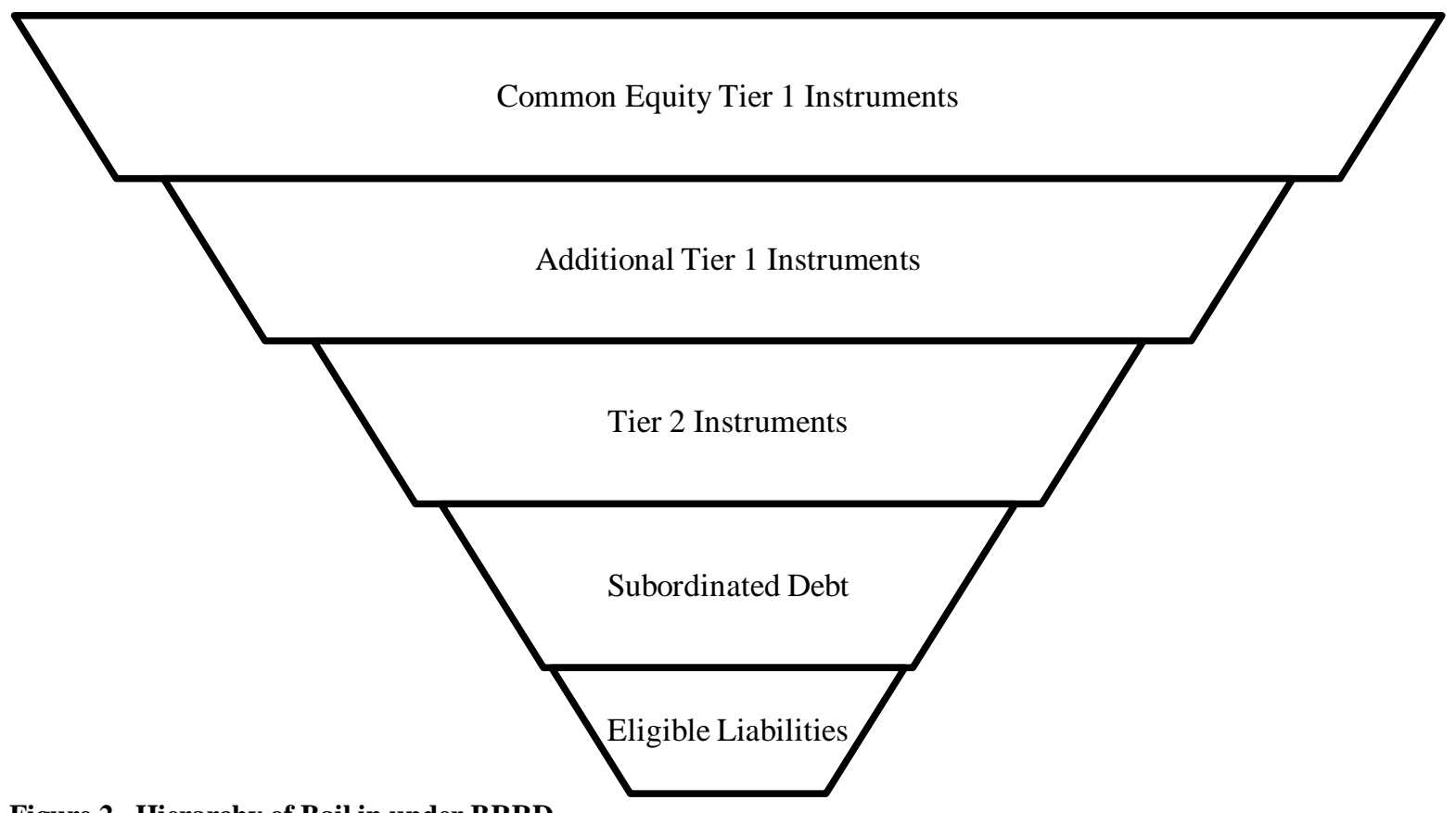

Figure 2. Hierarchy of Bail in under BRRD 
Banks shall be required to include clauses in agreements with creditors by which creditors acknowledge that the liabilities being created may be subject to a bail-in. ${ }^{34}$ Any actions taken under the bail-in provisions shall take effect and be immediately binding upon the affected banks. ${ }^{35}$

Both the BRRD and the Technical Standard suggest that holders of secured credit should not be affected by the changes brought about by bail-in provisions. This is because secured creditors and insured depositors fall within the scope of the exceptions to bail-inable debt. Their pre-existing right to claim repayment and repossess collateral from a nonperforming bank is not taken away. Conversely, unsecured creditors will most certainly be affected by the bail-in provisions, which grant authorities the power to convert their claims against failing banks into equity. This would increase their losses beyond what they would have suffered under alternative resolution regimes. Table 1 illustrates how the value of creditors' claims would be reduced where investors are obliged to bail-in the bank as a going concern, instead of the bank being allowed to face normal liquidation proceedings.

\footnotetext{
34 BRRD, art 55(1).

35 BRRD, art 53(10).
} 
Table 1. Loss Sharing Under Different Resolution Schemes

\begin{tabular}{|c|c|c|c|c|c|c|c|c|c|c|c|}
\hline \multicolumn{2}{|c|}{ Balance Sheet } & \multicolumn{2}{|c|}{$\begin{array}{c}\text { Liquidation (+DGS, No } \\
\text { DP) }\end{array}$} & \multicolumn{2}{|c|}{$\begin{array}{c}\text { Liquidation (+DGS, } \\
+ \text { DP) }\end{array}$} & \multicolumn{3}{|c|}{ Bail-out } & \multicolumn{3}{|c|}{$\begin{array}{l}\text { Bail-in (No insured deposits, No } \\
\text { secured Debt) }\end{array}$} \\
\hline Assets & Liabilities & Liabilities & $\begin{array}{l}\text { Recovery } \\
\text { Rate }\end{array}$ & Liabilities & $\begin{array}{l}\text { Recovery } \\
\text { Rate }\end{array}$ & Assets & Liabilities & $\begin{array}{l}\text { Recovery } \\
\text { Rate }\end{array}$ & Assets & Liabilities & $\begin{array}{l}\text { Recover } \\
\text { y Rate }\end{array}$ \\
\hline \multirow{4}{*}{$\begin{array}{l}\text { Remaining } \\
\text { Value of } \\
\text { Assets } \$ 70\end{array}$} & $\$ 10$ Secured & $\begin{array}{l}10 \\
\text { Secured }\end{array}$ & $\begin{array}{l}100 \\
\text { percent }\end{array}$ & $\begin{array}{l}10 \\
\text { Secured }\end{array}$ & $\begin{array}{l}100 \\
\text { percent }\end{array}$ & \multirow{4}{*}{$\begin{array}{l}\text { Remainin } \\
\mathrm{g} \text { Value } \\
\text { of Assets } \\
\$ 70\end{array}$} & $\begin{array}{l}10 \\
\text { Secured }\end{array}$ & $\begin{array}{l}100 \\
\text { percent }\end{array}$ & \multirow{4}{*}{$\begin{array}{l}\text { Remainin } \\
g \quad \text { Value } \\
\text { of Assets } \\
\$ 70\end{array}$} & $\$ 10$ Secured & $\begin{array}{l}100 \\
\text { percent }\end{array}$ \\
\hline & $\begin{array}{l}\text { \$40 Insured } \\
\text { Deposits }\end{array}$ & $\begin{array}{l}\text { \$40 Insured } \\
\text { Deposits } \\
\text { (\$10 from } \\
\text { the DGS) }\end{array}$ & $\begin{array}{l}100 \\
\text { percent } \\
(75 \\
\text { percent } \\
\text { without } \\
\text { DGS) }\end{array}$ & $\begin{array}{l}40 \\
\text { Insured } \\
\text { Deposits }\end{array}$ & $\begin{array}{l}100 \\
\text { percent }\end{array}$ & & $\begin{array}{l}\$ 40 \\
\text { Insured } \\
\text { Deposits }\end{array}$ & $\begin{array}{l}100 \\
\text { percent }\end{array}$ & & $\begin{array}{l}\text { \$40 Insured } \\
\text { Deposits }\end{array}$ & $\begin{array}{l}100 \\
\text { percent }\end{array}$ \\
\hline & $\begin{array}{l}\text { \$40 senior } \\
\text { Unsecured } \\
\text { Debt }\end{array}$ & $\begin{array}{l}\$ 30 \text { senior } \\
\text { Unsecured } \\
\text { Debt }\end{array}$ & $\begin{array}{l}75 \\
\text { percent }\end{array}$ & $\begin{array}{l}\text { \$20 senior } \\
\text { Unsecured } \\
\text { Debt }\end{array}$ & $\begin{array}{l}50 \\
\text { percent }\end{array}$ & & $\begin{array}{l}\text { \$40 senior } \\
\text { Unsecured } \\
\text { Debt }\end{array}$ & $\begin{array}{l}100 \\
\text { percent }\end{array}$ & & $\begin{array}{l}\$ 16.85 \\
\text { senior } \\
\text { Unsecured } \\
\text { Debt }\end{array}$ & $\begin{array}{l}42 \\
\text { percent+ } \\
\$ 3.15 \\
\text { Equity }\end{array}$ \\
\hline & & & & & & & & & & $\begin{array}{l}\$ 3.15 \\
\text { Equity }\end{array}$ & \\
\hline \multirow[t]{2}{*}{$\begin{array}{l}\$ 30 \text { Losses } \\
\text { on assets }\end{array}$} & $\begin{array}{l}\$ 2 \\
\text { subordinated } \\
\text { debt }\end{array}$ & $\begin{array}{l}\$ 0 \\
\text { subordinate } \\
\text { d debt }\end{array}$ & 0 percent & $\begin{array}{l}0 \\
\text { subordinat } \\
\text { ed debt }\end{array}$ & 0 percent & \multirow[t]{2}{*}{$\begin{array}{l}\text { Bail out } \\
\text { Subsidy } \\
\$ 30\end{array}$} & $\begin{array}{l}\$ 2 \\
\text { subordinat } \\
\text { ed debt }\end{array}$ & $\begin{array}{l}100 \\
\text { percent }\end{array}$ & & $\begin{array}{l}\$ 0 \\
\text { subordinate } \\
d \text { debt }\end{array}$ & 0 percent \\
\hline & \$8 Equity & \$0 Equity & 0 percent & \$0 Equity & 0 percent & & \$8 Equity & $\begin{array}{l}100 \\
\text { percent }\end{array}$ & & \$0 Equity & 0 percent \\
\hline \multicolumn{2}{|c|}{ BANK OPERATIONS } & \multicolumn{2}{|c|}{ DISCONTINUED } & \multicolumn{2}{|c|}{ DISCONTINUED } & \multicolumn{3}{|c|}{ CONTINUE } & \multicolumn{3}{|c|}{ CONTINUE } \\
\hline
\end{tabular}

Source: IMF Global Financial Stability Report: Transition Challenges to Stability ${ }^{36}$

Note: $D G S=$ Deposit Guarantee Scheme, DP = Depositor Preference

36 Hiroko Oura and others, 'Changes in bank funding patterns and financial stability risks' (IMF Global Financial Stability Report October 2013) ch 3 <http://www.imf.org/external/pubs/ft/gfsr/2013/02/index.htm> accessed 13 May 2014. 
In the example provided by Table 1 , the bank starts off with a balance sheet worth $\$ 100$, but suffers losses of $\$ 30$, leaving assets worth only $\$ 70$ against liabilities of $\$ 100$. The bank is now insolvent and has three options on how to proceed: it goes into liquidation, requests a bailout from the state, or it bails-in some of its liabilities. In liquidation proceedings, the bank's assets are sold and the amount recovered is used to pay creditors in the order of priority. Creditors whose claims are secured against some form of collateral have a senior claim and will recover the full amount owed to them, which in the example provided is $\$ 10$. Next in line to recover are senior unsecured debt holders and depositors whose claims rank parri passu, and will therefore have the same recovery ratio of $\$ 30$. However, when the claims of depositors are insured under a deposit guarantee scheme, (DGS), they will be fully paid by the DGS and the DGS will in turn take up the position of the depositors (this means that the DGS will have to cover the shortfall of $\$ 10$ to ensure that insured depositors receive their full $\$ 40$ ). The DGS and the holders of the remaining senior unsecured debt will make a partial recovery of $\$ 30$ each from the remaining assets. Subordinated debt holders and equity holders will not recover anything. In some countries there is the further complication of Depositor Preference (DP). This provides seniority to depositors over other senior unsecured debt holders at liquidation. Thus, depositors are paid first when asset recoveries are insufficient to repay all senior creditors, and their recovery ratios are higher. Moreover, the example illustrates that insured depositors will make a full recovery of $\$ 40$, leaving senior unsecured debt holders with only $\$ 20$. The position of subordinated debt holders and equity holders remains the same.

The second option for dealing with a failing bank is for the government to step in and provide a bail-out. In a bail-out, the government makes good on the losses of the bank either through an asset-protection scheme or by directly injecting capital into the business, to absorb the losses and add fresh equity buffers. In this case all of the bank's creditors recover 100 percent of their claims, and the $\$ 30$ cost of saving the bank is borne by taxpayers.

The third option for resolving a failing bank is that of bailing in. As highlighted in section B.2, secured debt and insured deposits are exempt from bail-in under the BRRD, all other liabilities remain eligible to be bailed in. Under the bail-in losses are first absorbed by equity and subordinate debt holders whose claims are wiped out. Senior unsecured debt holders are next to be bailed-in and their claims will be partly written down and partly converted into equity to restore the capital base of the bank. In the example the conversion values are set to achieve a 4.5 percent capital-to-asset ratio which is the minimum common equity capital 
Bail-In on Creditors' Property Rights

required for banks. ${ }^{1}$ As such senior unsecured debt holders will recover $\$ 16.85$ and $\$ 3.15$ worth of equity. Clearly, of the three options available for resolving a failing bank, bail-in offers the lowest rate of recovery for unsecured debt holders.

\section{BAIL-IN AND CREDITORS' PROPERTY RIGHTS}

\section{The Right to Property}

The bailing-in of liabilities represents a significant shift from traditional insolvency laws, in particular the right of eligible creditors to claim repayment of debts owed by failing banks. This is despite the fact that the laws of most jurisdictions have the effect that people may not be arbitrarily deprived of their property. While the concept and protection of 'the right to property' may vary greatly across different European states, the ECHR provides for a benchmark. ${ }^{2}$ 'The right to property is guaranteed in the Community legal order in accordance with the ideas common to the constitutions of the member states, which are also reflected in the first Protocol to the European Convention for the Protection of Human Rights. ${ }^{3}$

According to Article 1, Protocol 1 of the ECHR:

(1) Every natural or legal person is entitled to the peaceful enjoyment of his possessions. No one shall be deprived of his possessions except in the public interest and subject to the conditions provided for by law and by the general principles of international law.

(2) The preceding provisions shall not, however, in any way impair the right of a state to enforce such laws as it deems necessary to control the use of property in accordance with the general interest or to secure the payment of taxes or other contributions or penalties. $^{4}$

This right to property was confirmed by the ECtHR, in Marckx v Belgium ${ }^{5}$ where it was stated that 'by recognising that everyone has the right to the peaceful enjoyment of his possessions, Article 1 is in substance guaranteeing the right of property'. ${ }^{6}$ Moreover, in

\footnotetext{
${ }^{1}$ Bank of International Settlements, 'Basel III: A global regulatory framework for more resilient banks and banking systems - revised version June 2011' $<$ http://www.bis.org/publ/bcbs189.htm> accessed 18 August 2016.

${ }^{2}$ Tom Allen, Property and the Human Rights Act 1998 (Hart 2005) 7.

${ }^{3}$ Case 44/79 Hauer v Land Rheinland-Pfalz [1979] ECR 3727, 3745.

${ }^{4}$ Council of Europe, Protocol 1 to the European Convention for the Protection of Human Rights and Fundamental Freedoms.

${ }^{5}$ Series A No 31 (1979-80) 2 EHRR 330.

${ }^{6}$ ibid para 63.
} 
Sporrong and Lönnroth $v$ Sweden ${ }^{7}$ the ECtHR set out the three rules contained in Article 1 of Protocol 1, namely:

1. The principle of peaceful enjoyment of property. This is a general principle and is set out in the first sentence of the Article.

2. Prohibition against deprivation of possession and the conditions in which it may be carried out. This is in the second sentence of the Article.

3. The State's entitlement to control the use of property in accordance with general interest by enforcing such laws as it deems necessary. This is set out in the second paragraph of the Article.

The ECtHR has stated that the three rules are not distinct; therefore, although the second and third rules focus on interference with the right to property, they must be construed in light of the first rule which is the general principle that everyone has a right to peaceful enjoyment. ${ }^{8}$

\section{The Applicability Test: Do 'eligible liabilities' constitute property?}

The case law on property rights under Article 1 of Protocol 1 indicates that the ECtHR will usually rely on national law to determine what constitutes 'a possession'. ${ }^{9}$ This was made clear in the Marckx case, ${ }^{10}$ where the applicant challenged the provisions of the Belgian Civil Code which recognised that a child born out of wedlock did not have rights in the estate of its mother who died. Such a child only had the status of heir, but solely that of 'exceptional heir', and had to seek a court order putting him in possession of the estate. And even at that, the child was only entitled to three quarters of the estate where the mother had surviving relatives. The child was found not to hold any property until, and unless, the mother passed on and left the property to the child, as was required under Belgian law, therefore no claim could be brought against the State for infringing the child's right to property. ${ }^{11}$

In some cases, however, the Court has applied the 'autonomous meaning' doctrine to the interpretation of property. ${ }^{12}$ In Gasus Dosier-Und Fordertechnik GmbH v Netherlands, ${ }^{13}$ the applicant complained that the Dutch authorities had interfered with his right to property by seizing goods the applicant was holding for a client pending payment, to cover taxes owed by the client to the Dutch government. The Government contended that, under Dutch law, the

\footnotetext{
${ }^{7}$ Series A 52 (1983) 5 EHRR 35, para 61.

${ }^{8}$ Case 8793/79 James and Others $v$ United Kingdom Series A No 98 (1986) 8 EHRR 123, para 37.

${ }^{9}$ Case 17849/91 Pressos Compania Naviera SA v Belgium Series A No 332 (1996) 21 EHRR 301, para 31.

${ }^{10} \operatorname{Marckx}$ (n 5).

11 ibid.

12 Allen (n 2) 42.

13 [1995] 20 EHRR 403.
} 
Bail-In on Creditors' Property Rights

client to whom the goods had been sold was the true owner and the retention of title by the applicant merely amounted to a security interest. The ECtHR held, however, that the concept of possession could be extended beyond physical goods. It was held:

'possessions' [...] has an autonomous meaning which is certainly not limited to ownership of physical goods; certain other rights and interests constituting assets can also be regarded as 'property rights', and thus as 'possessions', for the purposes of this provision $\mathrm{P} 1(1) .{ }^{14}$

From the above, it can be concluded that a debt would constitute a possession to a creditor. The ECtHR reiterated in, Stran Greek Refineries $v$ Greece ${ }^{15}$ that the term 'possessions' under Article 1 of Protocol No. 1 can cover pecuniary assets, such as debts, and went further to state that the holder of the property must also have a legitimate expectation that he would have enjoyed the use of the possession. This highlights a further aspect, for a claim to be regarded as a possession it must be 'sufficiently established to be enforceable' under domestic law. ${ }^{16}$ For instance, the Dutch Civil Code provides that:

1. After the costs of foreclosure are paid, all creditors have, amongst each other, an equal right to be satisfied from the net sale proceeds of the foreclosed property of their debtor in proportion to the value of their debt-claims, except for rights of priority (preference) recognized by law.

2. The creditor and debtor may arrange by agreement that the debt-claim of the creditor in its relation towards the debt-claims of certain or all other creditors is ranked lower than it would be according to law. ${ }^{17}$

Similarly, in France, the French Civil Code provides, that:

A creditor may not be compelled to receive a thing different from the one which is owed to him, although the value of the thing offered is equal or even greater. ${ }^{18}$

Furthermore, in terms of the French Civil Code:

The property of a debtor is the common pledge of his creditors; and the proceeds of it shall be distributed among them pro rata, unless there are lawful causes of priority between the creditors. ${ }^{19}$

\footnotetext{
14 ibid para 53.

15 Series A No 301-B (1995) 19 EHRR 293.

16 ibid para 59.

${ }^{17}$ Art 3:277 BW.

${ }^{18}$ Art 1243 C. civ.

${ }^{19}$ Art 2285 C. civ.
} 
While it is agreed that an unsecured creditor has no right in the property of a debtor, the creditor's right to make a claim for repayment against a debtor constitutes property. In light of the above, the claims arising from liabilities deemed to be eligible under bail-in provisions constitute creditors' property. And where, under domestic insolvency law, the creditor has a legitimate expectation of succeeding in a claim for repayment of the debt against an insolvent debtor, eligible liabilities would, therefore, qualify as possessions.

\section{Will the bail-in tool interfere with the property rights?}

While Article 1, Protocol 1 of the ECHR provides for the peaceful enjoyment of one's property, the ECtHR has laid out two basic actions which constitute interference with such peaceful enjoyment and two sources of such interference. Deprivation and control of use ${ }^{20}$ are considered to be interferences with peaceful enjoyment, and such interferences can be in the form of either a public body exercising its executive authority, or a court decision or legislation, including an international legal instrument or constitution, which directly affects property rights. $^{21}$

$X v$ Federal Republic of Germany ${ }^{22}$ is illustrative of interference arising from a public body exercising its executive authority, while the Marckx case $^{23}$ illustrates the Court's view that legislation can be challenged on the basis that it directly interferes with property rights. In the Marckx case the Court held that 'Article 25 [...] of the Convention entitles individuals to contend that a law violates their rights by itself, in the absence of an individual measure of implementation, if they run the risk of being directly affected by it. ${ }^{24}$ In this case, the Belgian law on inheritance prevented the mother of a child born out of wedlock from deciding how she could dispose of her property, that is the option to leave her entire estate to her child.

The expression 'deprived of his possessions' in Article 1 of Protocol 1 of the EHCR was adjudged to apply only to someone who is 'deprived of ownership'. In Handyside $v$ the United Kingdom, ${ }^{25}$ the applicant in that matter, Mr Handyside, had published a schoolbook, for children aged 12 and upwards, which urged them to take a liberal attitude in sexual matters. The UK government proceeded to seize and subsequently destroy the publication based on the Obscene Publications Act 1959, and Mr Handyside complained that the seizure and

\footnotetext{
${ }^{20}$ Laurent Sermet, The European Convention on Human Rights and Property Rights (Council of Europe 1998) vol 88, 23.

21 ibid 22.

22 (1981) 4 EHRR 398.

${ }^{23} \operatorname{Marckx}$ (n 5).

24 ibid para 27.

${ }^{25}$ Case 5493/72 Handyside v the United Kingdom (1979) 1 EHRR 737 para 62.
} 


\section{Bail-In on Creditors' Property Rights}

destruction, among other things, breached Article 1 of Protocol 1 of the Convention. While the Court ruled that, in this case, the interference was justified in the general interest and therefore, not in contravention of the Convention, it did highlight that mere seizure of a possession did not amount to deprivation, as the individual is merely prevented 'from enjoying and using as he pleases possessions of which he remains the owner. ${ }^{26}$ The structure of the phrase in Article 1, Protocol 1 was interpreted in light of the original Belgian amendment of the sentence, which was drafted in French, in the 'travaux preparatoires'. The subsequent destruction of the $\mathrm{Mr}$ Handyside's publication was, however, considered deprivation because it permanently took away ownership. ${ }^{27}$

Direct deprivation ${ }^{28}$ of property can, therefore, take place where a public body transfers ownership in property to another person or entity, through expropriation, nationalisation, redistribution and reparcelling, or forced sale. Deprivation can also be indirect where the actions of a public authority, such as enactment of legislation, or a court ruling, oblige the owner of property himself to effect transfer of title. ${ }^{29}$ From the reasoning of the ECtHR in the Handyside case ${ }^{30}$ it follows, therefore, that control of use of property occurs where and individual remains the owner of the property but is prevented from exercising his full rights as owner of the property. The same reasoning was followed in the Marckx case, ${ }^{31}$ where the Court held that the provisions in the Belgian Civil code complained of did not result in deprivation of property, but barred the mother from disposing of the property as she wished. Therefore, the state was controlling the use of the property.

Based on the above, the final conversion or write down of a debt under a bail-in would constitute deprivation of property, as the creditors' right to claim repayment would be taken away. Holders of eligible debt would no longer be able to make a claim as the subject of the claim, the liability, falls away. Instead they will either be granted equity, which is altogether a different form of intangible property, as compensation, or the bank's debt is expunged.

\section{Will deprivation of property be justified?}

As Tom Allen notes, 'no constitutional or human rights instrument can guarantee a right to property that is both absolute and extensive. Either the right must be hemmed in by limitations

\footnotetext{
${ }^{26}$ Handyside (n 25) para 62.

27 ibid.

${ }^{28}$ Sermet (n 20) 23.

${ }^{29}$ ibid 23.

${ }^{30}$ Handyside (n 25).

${ }^{31} \operatorname{Marckx}(\mathrm{n} 5)$.
} 
and exceptions or it must be narrowly drawn. ${ }^{32}$ In the case of ECHR's Article 1, Protocol 1, the Court will justify interference with property only where it is lawful and where it is legitimate. ${ }^{33}$ The requirements for legality and legitimacy act as safeguards against arbitrary interference with the right to property.

a) Legality

From a reading of Article 1 of Protocol 1, in order for deprivation of property to be lawful it must be 'subject to the conditions provided for by law'. In the same vein, the state may control use of property in order 'to enforce such laws as it deems necessary'. In essence, the interference must be on the basis of some form of domestic law. Furthermore, the ECtHR has held that the phrase 'subject to the conditions provided for by law', in Article 1 of Protocol 1, does not simply refer to domestic law, but also the quality of the law, in that it must be compatible with the rule of law. ${ }^{34}$ Therefore, not only must the state comply with domestic law, when it takes actions which deprive individuals of their property, it must also comply with the general principles of the rule of law, ${ }^{35}$ that is the law 'must be sufficiently accessible, precise and foreseeable. ${ }^{36}$

The attempts of Slovenian financial regulators to bail-in the debts of bond holders underscored the importance of lawfulness in any deprivation of property. On December 42013 small debt-holders filed a case at the Constitutional Court of Slovenia challenging the legitimacy of the 2013 decision by the Bank of Slovenia to expropriate all holders of subordinated bonds and shares in six Slovenian banks, including all three of the country's systemically important banks. The Bank of Slovenia relied on the Banking Communication of 1 August 2013 as a basis for the complete write down of the selected debt, arguing that the Banking Communication required it to impose burden sharing between shareholders and subordinated debt holders before it could be allowed to provide state aid to failing banks. In the end creditors did not receive any compensation in return. ${ }^{37}$ The case was subsequently referred to the European Court of Justice (ECJ) for guidance on the validity and interpretation of the Banking Communication. ${ }^{38}$ The opinion of the Advocate General of the ECJ delivered on 18 February 2016, stated that firstly, the EU banking communications are not legally

\footnotetext{
${ }^{32}$ Allen (n 2) 101.

${ }^{33}$ Sermet (n 20) 32.

${ }^{34}$ James and Others (n 8) para 67.

35 Allen (n 2) 94.

${ }^{36}$ Case 24638/94 Carbonara and Ventura v Italy [2000] ECHR 206 at para 64.

${ }^{37}$ Commission, 'The Application, from 1 August 2013, of State Aid Rules to Support Measures in Favour of Banks in the Context of the Financial Crisis' COM (2013) 216 (Banking Communication).

${ }^{38}$ Case C-526/14 Kotnik and Others Advocate General's Opinion - 18 February 2016, Advocate General: Wahl.
} 
binding on Member States. Secondly, there is no duty to impose a compulsory write-down of subordinated debt, and thirdly, disproportionate burden-sharing is not a precondition for winning EU approval of state aid measures. As such, the expropriation of bond holder's property had no basis in law.

Future bail-in action in the EU will, however, certainly be conducted within the purview of the law. Member States were required to adopt and publish laws, regulations, and administrative provisions necessary to comply with this Directive as of 1 January 2015, while bail-in provisions became mandatory on the first of January 2016 as noted earlier. To date, 20 of the EU Member States have fully implemented the BRRD through national legislation, seven have mostly implemented and only one has partially implemented. ${ }^{39}$ Switzerland, although it is not required to implement the BRRD, has introduced a similar regime. ${ }^{40}$ It is interesting to note that of the eight countries which are the home regulators of banks which have been designated as systemically important, only Germany, Italy, Netherlands, Spain, and Sweden have fully implemented the BRRD, while Belgium, the UK, and France have implemented most, but not all, of the provisions of the BRRD.

While the requirement of having legislative basis for bail-in can easily be fulfilled, ensuring that bail-in rules conform to the general principles of the rule of law may be more difficult. In particular, Article 44(3) does not provide for precision and foreseeability in the designation of liabilities excluded from bail-in, beyond those listed in Article 44(2), and this leads to contradictions in the law. In principle all liabilities are eligible for bail-in and the EBA Technical Advice on Exclusion from the Bail-in Tool suggests that Member States' delegated acts should not specify that certain liabilities will always be excluded from bail-in because this would be contrary to the Level 1 text. ${ }^{41}$ The technical standard on MREL requires resolution authorities to take into account any possible exclusions when deciding on the level of MREL for a firm, which somewhat indicates future exclusions. The only limitation to the exercise of discretion is that any ad hoc exclusion of liabilities can only be done in 'exceptional circumstance'. The provisions (a) to (d) in Article 44(3) provides that exceptional circumstances exist when:

a) It is not possible to bail-in that liability within a reasonable time;

\footnotetext{
${ }^{39}$ International Swaps and Derivatives Association, European Bank Recovery and Resolution Directive (BRRD)

- Monitor of Implementation (3rd ed ISDA 2016).

40 ibid.

${ }^{41}$ European Banking Authority, 'Technical Advice on Exclusion from the Bail-in Tool' Op (2015) 07.
} 
b) The exclusion is strictly necessary and is proportionate to achieve the continuity of critical functions and core business lines in a manner that maintains the ability of the institution under resolution to continue key operations, services and transactions;

c) The exclusion is strictly necessary and proportionate to avoid giving rise to widespread contagion; and

d) The application of the bail-in tool to those liabilities would cause a destruction in value such that the losses borne by other creditors would be higher than if those liabilities were excluded from bail-in.

With the exception of the third criterion, the avoidance of contagion, the benchmarks for exceptional circumstances present obvious problems. Firstly, the BRRD does not define 'reasonable time', although the technical advice outlines a number of legal and practical obstacles which can make bail-in impossible within a reasonable time. Secondly, the assessment of 'critical functions' will have to be conducted on a case-by-case basis because it depends on the size, market share, external and internal interconnectedness, complexity, or cross-border activities of a firm. It is impossible to devise a general definition in advance of firms whose activities would fall in the purview of critical functions. Core business is more easily defined as it consists of business lines and associated services which represent material sources of revenue, profit or franchise value for the firm. ${ }^{42}$ Thirdly, even if some certainty or predictability could be guaranteed, the exclusion of some or all liabilities would deviate from the pari passu principle which requires equal treatment of creditors in the same class in insolvency proceedings. Article 34(1)(f) of the BBRD generally upholds the pari passu principle and provides that creditors of the same class have to be treated in an equitable manner, except where otherwise provided in the BRRD. Article 48(2) on the other hand explicitly authorises a deviation from pari passu and provides that liabilities excluded from bail-in may receive a more favourable treatment than eligible liabilities that are of the same rank in insolvency proceedings. However, there is no clear situation in which deviation can or should occur. The preferential treatment of some creditors becomes particularly problematic where some creditors bear greater losses than they would have under insolvency proceedings which recognise equal treatment of creditors in the same class.

The recent case of Portuguese bail-in is illustrative of the lack of sufficient generality, the possibility for contradictions and how bail-in rules are not prospective. In August 2014

${ }^{42}$ BRRD, art 2(1)(36). 


\section{Bail-In on Creditors' Property Rights}

resolution proceedings were initiated against Banco Espirito Santo, SA, (BES), after it announced losses. The Bank of Portugal used the bridge institution tool and split BES into a bad bank, which retained all the toxic assets and liabilities to be written down; and a good bank, to which all the good assets and liabilities were transferred, called Novo Banco. A 2015 assessment carried out by the ECB revealed a capital shortfall of $€ 1.4$ billion on the balance sheet of Novo Banco and on 29 December 2015 the Bank of Portugal decided to transfer back to the bad bank five out of 52 available senior bonds to cover the shortfall, effectively writing down the debt held under the five bonds. While the re-transfer is permissible under Article 40(7) of the BRRD, the basis on which the five bonds were selected out of a total of 52 has raised questions. It appears, however, that rather than there being 'exceptional circumstance', the selection was motivated by a desire to avoid writing down debt which is subject to the jurisdiction of foreign law and might therefore trigger lawsuits before foreign Courts less sympathetic to the Portuguese regulator. ${ }^{43}$ Apart from the confusion created by changing the status of liabilities, investors in the five can argue that the Bank of Portugal has subjected them to unequal treatment in comparison to creditors in the same class. ${ }^{44}$

\section{b) Legitimacy}

The legitimacy of actions which deprive individuals of their property, on the other hand, is achieved if the interference is in the 'public interest' or 'general interest'. The case of James and Others $v$ United Kingdom ${ }^{45}$ summed up the requirements for legitimacy. The applicants in the matter contended that the compulsory transfer of their property under the Leasehold Reform Act 1967 was in violation of Article 1 of Protocol No 1 to the Convention. The Leasehold Reform Act conferred 'on tenants residing in houses held on "long leases" (over, or renewed for periods totalling over, 21 years) at "low rents" the right to purchase compulsorily the "freehold" of the property (the ground landlord's interest) on prescribed terms and subject

\footnotetext{
${ }^{43}$ Martin Arnold and Peter Wise, 'Novo Banco Investors Threaten Legal Action over €2bn Losses' Financial Times (London 30 December 2015)

<http://www.ft.com/intl/cms/s/0/da45fb10-aede-11e5-993b-c425a3d2b65a.html\#axzz48eKKKPfg> accessed 20 April 2016; See for instance Goldman Sachs International and Others v Novo Banco S.A. [2015] EWHC 2371 (Comm).

${ }^{44}$ German legislators attempted to create more certainty in the law by establishing statutory subordination of particular senior unsecured debt instruments (namely tradable bearer bonds, promissory notes and registered bonds) below other unsecured debt. Eventually these proposals in the draft legislation were abandoned and the final Act stipulates that the claims of senior unsecured creditors will be are satisfied after the claims of all other creditors unsubordinated creditors have been satisfied. Therefore, such liabilities are not formally subordinated by law and preserve their seniority in relation to subordinated obligations, however, they are treated as junior to all other obligations of the insolvent debtor. See the German Resolution Mechanism Act, (Abwicklungsmechanismusgesetz - AbwMechG), which amended section 46f of the German Banking Act, (KWG), dealing with the ranking of creditors in bank insolvency.

${ }^{45}$ James and Others (n 8).
} 
to certain prescribed conditions. ${ }^{46}$ The applicants owned 80 pieces of property which had been affected by legislation.

The ECtHR was in agreement with the applicants that they had indeed been deprived of their property within the meaning of Article 1 of Protocol 1. However, it disagreed with the applicant's notion that the deprivation was not justified if the government transferred private property for the private benefit of another. First, the Court made no distinction between 'public interest' and 'general interest', as it found no fundamental distinction between the two. Secondly, it held instead that deprivation of property could be considered to be in the 'public interest' if 'the taking is effected in pursuance of legitimate social policies.' ${ }^{47}$ The concept of 'public interest' is broad and, therefore, not limited to the transfer of property only where the whole community, or a significant portion of it, will benefit directly from the property.

Furthermore, the ECtHR acknowledged that a margin of appreciation should be granted to national authorities 'because of their direct knowledge of their society and its needs [...] [they are] in principle better placed than the international judge to appreciate what is 'in the public interest' ${ }^{48}$ The Court, therefore, will not interfere with the decisions of legislature, unless they are manifestly unreasonable. And, in order to determine whether the actions are without reasonable foundation, the Court will look at the principle and facts which prompted the national authorities to act. ${ }^{49}$ In the case of James, the ECtHR found that the UK's Parliament was reasonable in concluding that the previous leasehold laws had resulted in social injustice towards tenants, and reform was required to regulate more fairly the relationship of landlord and tenant. ${ }^{50}$

Legitimacy of bail-in measures may be argued on the basis that it provides governments with an alternative tool from having to bail-out failing banks using tax payer funds. A process which can and has in the recent past placed a heavy burden on taxpayers. Furthermore, it assists in establishing an effective resolution system which is necessary to curb excessive risk taking by banks, which was one of the causes of the GFC. The administrative ruling authorising the resolution of Austrian firm Heta Asset Resolution AG (HETA) further demonstrates how resolution actions can be in the 'public interest'. ${ }^{51}$ On 1 March 2015 the Austrian Financial

\footnotetext{
46 ibid para 11.

47 ibid para 39.

48 ibid.

49 ibid para 22.

50 ibid.

${ }^{51}$ Mandatsbescheid Heta Asset Resolution AG WIEN, AM 01.03.2015

<https://www.fma.gv.at/en/resolution-of-heta-asset-resolution-ag/> accessed 10 May 2016.
} 
Bail-In on Creditors' Property Rights

Market Authority (FMA), in its capacity as the Austrian resolution authority, initiated the resolution of 'Heta Asset Resolution AG' in accordance with the Austrian Federal Act on the Recovery and Resolution of Banks (BaSAG), which transposed the BRRD. HETA is the 'bad bank' that was established as a wind-down vehicle to assume and manage the remaining viable assets and liabilities of the failed Austrian bank, Hypo Alpe Adria. Initially the FMA imposed a 15-month moratorium on the liabilities of HETA until 31 May 2016, and eventually announced that part of the eligible liabilities would be written down once the moratorium had expired, leaving creditors to face an estimated 54 percent haircut. ${ }^{52}$ The FMA held that the moratorium was in the public's interest because HETA's insolvency would:

i. Affect the continuity of critical functions of HETA's former subsidiaries in Southeast Europe; and ${ }^{53}$

ii. Have material adverse effects on the stability of the financial markets of member states in Southeast Europe where those former subsidiaries were still active, namely Croatia and Slovenia, and some non-EU member states, namely Serbia, Bosnia, and Montenegro. ${ }^{54}$

The need to maintain financial stability, therefore, offers a strong public interest reason for instituting bail-in.

Having established that the legislature is justified, in principle and in fact, in taking a particular decision, it is also necessary to determine whether the means chosen to achieve the aim are proportional. 'A fair balance must be struck between the demands of the general interest of the community and the requirements of the protection of the individual's fundamental rights. ${ }^{55}$ The Court echoed the judgements passed in the Lithgow v United Kingdom ${ }^{56}$ case in this regard. One way of striking such a balance is the provision of compensation for the loss of property as highlighted in Lithgow. ${ }^{57}$ In James it was held that the compulsory transfer of the freehold interest from the landlord to the tenant, with financial compensation to the landlord, could not be deemed as an inappropriate or disproportionate method for adjusting the law in order to remove the social injustice complained of. ${ }^{58}$

\footnotetext{
${ }^{52}$ Mandatsbescheid Heta Asset Resolution AG WIEN, AM 01.03.2015

$<$ https://www.fma.gv.at/en/resolution-of-heta-asset-resolution-ag/> accessed 10 May 2016.

53 ibid 26.

54 ibid 28.

55 Sporrong and Lönnroth (n 7) para 69.

${ }^{56}$ Series A No 102 (1986) 8 EHRR 329 para 120.

57 ibid para 120.

58 James and Others (n 8).
} 
Holders of eligible liabilities face two possible outcomes in a bail-in: either they will be compensated with equity for the loss of their pecuniary assets, or the debt will be partially or completely written down, without any form of compensation. The second outcome is clearly disproportionate, and provides grounds for challenging the legitimacy of bail-in actions. The BRRD is cognisant of the need to maintain proportionality and stipulates that in the case of bail-in then no creditor should be left worse off.

The 'no creditor worse off' principle, (NCWO), which appears in Article 73 of the BRRD, simply means that "no creditor should be worse off under resolution than it would have been had the bank been wound up under applicable insolvency law proceedings. ${ }^{59}$ It can be defined in two ways; firstly, the conversion or write down of debt would follow the order of allocation of losses under insolvency proceedings. ${ }^{60}$ Secondly, creditors can claim compensation if they do not receive the minimum which they would have received under insolvency. ${ }^{61}$ In essence, it replaces the creditor's right to claim repayment with a right to claim compensation from the resolution fund. The assessment of whether creditors have been left worse off is based on a comparison between the proceeds received by shareholders and creditors under the resolution decision after an independent valuation of the bank and the proceeds those shareholders and creditors would have theoretically received under insolvency. The EBA has published a draft regulatory technical standard (RTS) on valuation to determine difference in treatment following resolution.

NCWO, however, seems to be an untenable safeguard because, far from clarifying the situation, it will increase instances of litigation as creditors claim that they have been left worse off than they would have, particularly in countries where senior creditors and subordinated creditors usually rank pari passu under ordinary insolvency procedures and share the costs of insolvency. Furthermore, it raises the question of where the funds to compensate creditors will come from. It seems likely that member state governments would eventually have to step in and provide this compensation, which is tantamount to the safety net provided under a bail-out, albeit at a lower scale, because resolution funds are relatively new and unlikely to have sufficient levels of funding to cover the claims. However, the BRRD requires that a minimum

\footnotetext{
${ }^{59}$ Commission, 'EU Bank Recovery and Resolution Directive (BRRD): Frequently Asked Questions' Memo (2014) 297.

${ }^{60}$ Flora Prieto, 'No creditor worse off': resolution mechanisms update' (2013) Global Risk Update 3, 4 〈http://www.riskrewardlimited.com/admin/pdf/GRU\%20May13\%20Flora\%20Prieto.pdf〉 $\quad$ accessed 2 September 2016.

61 ibid.
} 
Bail-In on Creditors' Property Rights

amount of 8 percent of total liabilities be bailed in before any assistance from the resolution fund can be provided.

The Italian government's decision to set up a hardship compensation following a bailin is indicative of the need to balance public interests and individual property rights. The decision was prompted by public outcry following the bailing-in of subordinated bondholders in four small regional banks in 2015. Depositors and senior bondholders were exempted from the bail-in. In a similar vein, the Bank of Portugal offered to compensate creditors who were affected by the re-transfer of bonds from the good bank to the bad bank. ${ }^{62}$

It cannot be disputed that regulatory reforms were necessary in the area of bank resolution, given the rampant moral hazard problem and the costs incurred by taxpayers due to the too-big-to-fail subsidy. The BRRD certainly fulfils this reform mandate. However, it is not without a cost, which comes in the form of creditors' property rights being curtailed. Ordinarily a state may derogate from the right to property if it can be shown that its actions are legal and legitimate - and herein lies the problem with the BRRD. It does not fully satisfy the legality requirement as it lacks consistency, sufficient generality, and has been applied in a retrospective manner. On the other hand, it does not satisfy the legitimacy requirements as it can lead to disproportionate outcomes where creditors bear more losses than they would have under normal insolvency proceedings.

Two possibilities are suggested for curbing the legal risk noted above which accompanies bail-in: either ensuring that at the end of a bail-in no creditor is indeed left worse off by providing ex post compensation in every instance, or promoting the use of financial instruments which allow banks and their creditors to decide for themselves ex ante how losses should be absorbed, through contractual means. The two ideas are discussed in the next section.

\footnotetext{
${ }^{62}$ Martin Arnold and Peter Wise, 'Portugal Offers Investors in Novo Banco compensation to quell anger' Finanical Times (London \& Lisbon 20 January 2016) <http://www.ft.com/intl/cms/s/0/e440594a-bf95-11e59fdb-87b8d15baec2.html\#axzz48eKKKPfg> accessed 11 April 2016.
} 


\section{ALTERNATIVE PROPOSALS}

\section{Ex post compensation through resolution funds}

In terms of the BRRD, all Member States are required to create financing arrangements, in the form of a fund, for the effective application of resolution tools and powers. ${ }^{63}$ As of 1 January 2016, a Single Resolution Fund (SRF) has replaced the national resolution fund in those EU countries which are part of the Banking Union and are subject to the Single Resolution Mechanism. The authorised uses of a resolution fund include:

i. Guaranteeing the assets or the liabilities of an institution under resolution;

ii. Lending to an institution under resolution;

iii. Purchasing the assets of an institution under resolution;

iv. Contributing to a bridge institution and an asset management vehicle;

v. Compensating shareholders or creditors in accordance with Article 75 of the BRRD;

vi. Recapitalising an institution under resolution in lieu of bailing-in liabilities of certain creditors;

vii. Lending to other resolution funds.

Going back to the discussion on how to ensure legitimacy of bail in rules, resolution funds can therefore be used to avoid disproportionate outcomes from bail-in proceedings. In theory no creditor will be left worse off since a resolution fund can be used to pay the difference to any shareholder or creditor who has incurred greater losses than they would have incurred in a winding up under normal insolvency proceedings. All this of course is subject to the availability of finances in the resolution funds. As such, the resolution funds are required to ensure that, by 31 December 2024, the available financial resources reach at least 1 percent of the amount of covered deposits of all the institutions authorised in the territory. ${ }^{64}$ In the Banking Union, the SRF also has a target level of at least 1 percent of the amount of covered deposits of all the institutions authorised in the euro area. Should a State fail to meet the target by 2024 , the contribution period can be extended by four years, if such failure was due to the resolution fund having made cumulative disbursements in excess of 0.5 percent of covered deposits of all the institutions authorised in its territory.

The Commission Regulation on Resolution financing arrangements provides guidance on the structure of resolution funds. ${ }^{65}$ Finance is raised through ex-ante contributions from

\footnotetext{
${ }^{63}$ BRRD, art 100.

${ }^{64}$ BRRD, art 103.

${ }^{65}$ Commission Delegated Regulation (EU) 2015/63 of 21 October 2014 supplementing Directive 2014/59/EU of the European Parliament and of the Council with regard to ex ante contributions to resolution financing arrangements OJ L11/44 (RRF).
} 
Bail-In on Creditors' Property Rights

banks, which will be collected until the target level is reached. Individual institutions are required to make a fixed contribution to the resolution fund, which is calculated based on the institution's size, which in turn is measured by the amount of institution's liabilities, excluding own funds and guaranteed deposits. ${ }^{66}$ As such, larger banks will be required to make larger contributions. This fixed amount shall not, however, exceed 30 percent of the total amount of contributions raised by the fund. In addition, this basic contribution is adjusted according to the risk profile of the institution, which is determined using the four risk pillars of i) risk exposure, ii) stability and variety of sources of funding, iii) importance of institution to the stability of the financial system, and iv) additional risk indicators which can be determined by the resolution authority. ${ }^{67}$ It is recognised, however, that small institutions have a lower risk profile and are less likely to make use of resolution funds, therefore they are not subject to the same risk adjustment system. Instead, small banks are required to pay a lump-sum to account for any additional risk. ${ }^{68}$ In the Banking Union, small banks, which represent 1 percent of the total assets, would pay 0.3 percent of the total contributions in the euro area.

Resolution funds can spread out contributions over time as evenly as possible until the target level is reached, but with due account of the phase of the business cycle and the impact pro-cyclical contributions may have on the financial position of contributing institutions. ${ }^{69}$ In the event that the funds prove insufficient in the face of a crisis, despite meeting the target, then resolution authorities may request ex-post contributions to cover any losses, costs or other expenses incurred. ${ }^{70}$ However, until sufficient funds have been built up, the resolution funds remain powerless and the BRRD itself anticipates that it will take at least nine years, which can be extended to thirteen, to meet the target reserves. In the meantime, many banks have not fully recovered from the effects of the GFC and are still facing failure. Resolution authorities have not been able to keep up with the compensation demands and it is likely governments will have to step in and lend money to the funds - which in effect is providing a bail-out, the very thing the BRRD sought to avoid.

The difficulty of trying to build a resolution fund in the midst of a struggling financial sector was made apparent in the case of Italy. As highlighted earlier, the Italian regulator bailed-in four small regional banks in November 2015, namely Banca Marche, Banca Popolare

\footnotetext{
${ }^{66} \mathrm{RRF}$, art 5.

${ }^{67} \mathrm{RRF}$, art 6, 9.

${ }^{68} \mathrm{RRF}$, art 10.

${ }^{69}$ BRRD, art 102(2).

70 ibid.
} 
dell'Etruria e del Lazio, Cassa di Risparmio di Ferrara, and Cassa di Risparmio di Chieti. In order to rescue the previously mentioned banks, Italy formed a National Resolution Fund. Ideally healthy banks are supposed to contribute to a resolution fund, however Italian banks could not raise the $€ 3.6$ billion needed for the resolution fund to become immediately operational. The liquidity required for the resolution was instead advanced by Italy's three largest banks, Banca Intesa Sanpaolo, Unicredit, and UBI Banca, at market rates and with a maximum maturity of 18 months. ${ }^{71}$ This was essentially a three-year advance to the National Resolution Fund since Italian banks are only required to make annual contributions of around $€ 600$ million. The cost of the loans is supposed to be defrayed by the Italian banking system as a whole through its contributions to the National Resolution Fund. However, State bank Cassa Depositi e Prestiti provided a guarantee for $€ 1.65$ billion if one of the loans could not be repaid in 18 months' time. In effect, tax payers' money is still at risk of being used to rescue failing banks, which defeats the spirit of bail-in.

It seems therefore that trying to ensure that no creditor is left worse ex post may not be possible given the difficulties in raising the funds, which will be required to compensate creditors who have been left in a worse position than they would have been had the bank gone through normal insolvency procedures. Furthermore, even if resolution funds were sufficiently financed, they only address the problems with legitimacy of bail-in rules, namely that the rules can produce disproportionate outcomes. The gaps in the rule of law remain, in that the criteria for excluding liabilities are not sufficiently general; liabilities which were created before the rules came into force can be bailed in; and this can result in actions which contradict the pari passu principle since creditors in the same class can be treated differently.

Perhaps the answer lies in regulators playing a limited role and instead allowing private parties to decide for themselves which liabilities will be bailed-in; how and when such bailingin will occur; and any premiums on loans to compensate for losses due to bail-in. In effect, regulators would adopt a contractual approach to bail-in as opposed to a statutory one, which has stricter legality and legitimacy requirements, in order to avoid infringing on property rights. Currently, contingent convertible bonds, commonly referred to as CoCos, offer the most promising avenue for such an approach.

\footnotetext{
${ }^{71}$ Banca D'Italia, 'Information on resolution of Banca Marche, Banca Popolare dell'Etruria e del Lazio, Carichieti, and Cassa di Risparmio di Ferrara crises'

<https://www.bancaditalia.it/media/approfondimenti/2015/info-soluzionecrisi/index.html?com.dotmarketing.htmlpage.language $=1>$ accessed 10 June 2016.
} 
Bail-In on Creditors' Property Rights

\section{Ex ante negotiation of bail-in through contingent convertible bonds}

Contingent convertible bonds are a hybrid form of capital that may be converted into common equity, or be subjected to a write-down of part or all of the principle amount due. ${ }^{72}$ Banks primarily use CoCos to satisfy regulatory capital requirements, as they can absorb losses, thus replenishing the issuer's balance sheet before the firm becomes insolvent and has to face resolution proceedings. Both conversion and write-down are effected upon the occurrence of a predetermined event, known as a trigger, which is usually linked to the issuer's financial position. The trigger itself can either be mechanical or discretionary. A mechanical trigger is activated when the capital of the firm falls below a predetermined level (which is based on either a book value or market value of the capital). ${ }^{73}$ In contrast, a discretionary trigger is activated by a supervisory authority when it deems that the firm is nearing insolvency, in other words, a point of non-viability. ${ }^{74}$

In the wake of the GFC, European governments have encouraged the use of CoCos in fulfilling capital requirements and, consequently, created a framework to govern the issuance of CoCos, under the Capital Requirements Directive ${ }^{75}$ and the Capital Requirements Regulation ${ }^{76}$ - collectively referred to as 'CRD IV' - which set the minimum capital requirements for banks. The European market for CoCos grew from almost being non-existent to $€ 93$ billion between 2013 and 2016, and it is projected to reach $€ 226$ billion by 2020 . $^{77}$ However, complexity in the current EU rules for CoCos could undermine their efficacy and actually erode a bank's financial position in a crisis.

In terms of the CRR, CoCos are eligible for treatment as either Additional Tier 1 Capital (AT1) or Tier 2 Capital (T2), depending on which features they contain. Section 1 of Chapter 3 of the CRR sets out the requirements which must be met for any financial instruments to

\footnotetext{
72 Association for Financial Markets in Europe, 'Prevention and cure: securing financial stability after the crisis' (2010) 47, <http://www.afme.eu/> (AFME) accessed 10 June 2016.

73 Stefan Avdjiev and others, 'CoCos: a primer' (2013) BIS Quarterly Review 43-56, 44, <http://www.bis.org/publ/qtrpdf/r_qt1309f.pdf> accessed 15 June 2016.

74 ibid.

${ }^{75}$ Directive 2013/36/EU of the European Parliament and of the Council of 26 June 2013 on access to the activity of credit institutions and the prudential supervision of credit institutions and investment firms, amending Directive 2002/87/EC and repealing Directives 2006/48/EC and 2006/49/EC OJ 2013 L176/338 (CRD IV).

${ }^{76}$ Corrigendum to Regulation (EU) No 575/2013 of the European Parliament and of the Council of 26 June 2013 on prudential requirements for credit institutions and investment firms and amending Regulation (EU) No 648/2012 OJ 2013 L321/6 (CRR).

${ }^{77}$ Martin Arnold and Thomas Hale 'ECB is having second thoughts on 'coco' bonds' Financial Times (London April 24, 2016) http://www.ft.com/cms/s/0/23d61e50-08a7-11e6-b6d3-746f8e9cdd33.html\#axzz4EmIFXZMm accessed 14 July 2016.
} 
qualify as AT1 capital. Among the plethora of requirements there are a few which have a significant effect on CoCos, namely that AT1 instruments:

i. $\quad$ are subordinate to Tier 2 instruments;

ii. cannot be secured or benefit from any other arrangement that otherwise enhances their seniority;

iii. are perpetual;

iv. do not include an incentive for the institution to redeem them;

v. may be called, redeemed or repurchased only with supervisory permission if either the capital is replaced with other instruments of equal or higher quality and at sustainable terms; or the issuer's own funds exceed capital requirements; ${ }^{78}$

vi. do not have provisions indicating that the issuer may call, redeem or repurchase the instruments;

vii. may be cancelled at the issuer's discretion, on a non-cumulative basis, without this constituting an event of default, while distributions on instruments are payable only out of distributable items;

viii. permit a write down of the principal amount on a permanent or temporary basis, or conversion of the principal amount to equity upon occurrence of a trigger event; and

ix. do not contain any feature that could hinder a recapitalisation of the institution. ${ }^{79}$

On the other hand, the criteria for financial instruments to qualify as T2 capital are less stringent and are set out in Section 1 of Chapter 4 of the CRR. Again of interest is that CoCos which qualify as T2 financial instruments:

i. are subordinate to claims of all non-subordinated creditors;

ii. do not secure or benefit from any other arrangement that otherwise enhances their seniority;

iii. have an original maturity of at least five years;

iv. do not include any incentive to be redeemed or repaid prior to maturity;

v. are subject to a call option at the issuer's discretion, subject to the same preconditions applicable to AT 1 instruments;

vi. do not include acceleration provisions in favor of the holders. ${ }^{80}$

Two concerns arise from the particular rules highlighted above. Firstly, while ordinarily creditors who hold CoCos know that there is a risk of losing the principal amount of the debt,

\footnotetext{
${ }^{78}$ The conditions which must be met for the Supervisor to give such authorisation are contained in CRR art 77 .

${ }^{79}$ CRR art 52, 53 and 54.

${ }^{80}$ CRR art 63.
} 
Bail-In on Creditors' Property Rights

the CRR makes it possible for banks to miss coupon payments as well, in order to avoid breaching capital requirements. Thus, creditors risk losing both principal and interest. Secondly, in the case of CoCos held as AT1, there is uncertainty over whether creditors will ever get their initial investment back, since the bonds are perpetual, meaning they will not mature unless the bank exercises an option, and even then it is subject to the approval of regulators. In order to avoid anxiety amongst investors, which would in turn lead to them dumping the bonds at whatever price they can get, regulators would need to consider changes to the law to clarify the current uncertainty around the instruments.

Regardless of the concerns highlighted above, CoCos still represent the ideal loss absorption instrument in that they allow recapitalisation of failing institutions in a way which allays the maintains creditors' property rights. CoCos differ from bail-in in that their conversion or write down is contractually agreed in advance between issuers and investors. Bail-in is directed by a public authority which decides the point at which bail-in occurs, whether it will take place through conversion or write down, which debts will be bailed-in, and the rates of conversion or writing down. The only limitations on this exercise of power are the regulations governing bail-in, but as we have seen, these regulations lack clarity, consistency, and are not sufficiently general and prospective. Furthermore, apart from liabilities excluded by law, creditors in a bail-in do not know in advance whether their particular debt will be selected for bail-in and thus cannot negotiate for a coupon which reflects the risk or for conversion at a particular rate. ${ }^{81}$

In contrast, from an investor's point of view, a CoCo bond provides certainty as the investor knows in advance whether the loss will be absorbed through conversion or written down, the point at which conversion or write down will be triggered, and in the case of conversion, the conversion ratio. ${ }^{82} \mathrm{CoCos}$ offer the same advantage to issuers, but more importantly control over the trigger point allows them to absorb losses at a point early enough that issuers can avoid failure and limit loss absorption to a particular class of debt which hopefully reduces the cost of its other debt. ${ }^{83}$ Overall, the market benefits from a reduced risk of regulatory forbearance and/or arbitrariness in recapitalisation, as the public authority's role

\footnotetext{
${ }^{81}$ CRR art 63.

${ }^{82}$ Andreas Cahn and Patrick Kenadjian, 'Contingent convertible securities: From theory to CRD IV' (2014) Institute of Law and Finance, Goethe-Universität Frankfurt Am Main Working Paper Series NO. 143/2014. 83 ibid.
} 
is limited, while the risk of resolution and thus the loss of critical functions is also reduced as recapitalisation can take place early on while the bank is still a going concern. ${ }^{84}$

The greatest advantage however, is that CoCos can actually be used within the bail-in framework and satisfy the MREL. As part of bank capital, they contribute to the bank's loss absorption capacity, which is one of the criteria for determining the level of MREL to be held by a bank in terms of the BRRD. Thus, by requiring firms to hold a proportion of their bail-in eligible debt in CoCo bonds, regulators would be allowed to achieve the twin aims of recapitalisation, or in the worst case orderly resolution of a bank, without recourse to public funds and without infringing creditors' property rights. A final question of course would be on the level of CoCos a bank would need to hold to absorb losses and restore viability, a question with which bankers, academics and regulators alike are now grappling. ${ }^{85}$

\section{E. CONCLUSION}

The right to property allows the State to control the use of property in accordance with general interest by enforcing such laws as it deems necessary - in other words interference in lawful and legitimate circumstances. The ECtHR has defined legality as both having a basis in law and adhering to principles of the rule of law; while legitimacy means the aim must be in the public interest, both in fact and principle, and the means of executing the aim are proportional.

Bail-in rules, in particular the designation of liabilities eligible for bail-in, fall short principles of the rule of law in that the criteria for exception is not sufficiently general; the rules have not been applied in a prospective manner because they are affecting liabilities which were created before the enactment of the bail-in legislation; and they have resulted in contradictions where authorities have changed the status of eligible liabilities. Furthermore, bail-in measures can be disproportionate where the debts are written down without any compensation to the holders of eligible liabilities, thus eroding the legitimacy of bail-in.

In theory the last problem highlighted, that of disproportionate outcomes, can be resolved by ensuring that there is 'No Creditor Worse Off', one of the principles of the BRRD. As such, the BRRD mandates states to create resolution funds which may be used, among other things, to compensate creditors who have been left worse off than they would have under normal insolvency proceedings. In practise, however, compensation in every instance has proven untenable as it requires an inexhaustible source of funds and would actually result in

\footnotetext{
84 ibid.

85 ibid 11-18; Louise Pitt and others, 'Contingent capital, possibilities, problems and opportunities' Goldman Sachs Global Markets Institute (March 2011), 8.
} 


\section{Bail-In on Creditors' Property Rights}

the moral hazard similar to that created by government guarantees. Furthermore, there are still gaps in the rule of law which must be addressed.

The most viable option would therefore be promoting or organising regulations around the use of funding instruments that allow investors and borrowers to define ex ante through contractual means which liabilities will be bailed-in; and how and when such bailing-in will occur. Furthermore, using contracts to define how and when bail-in occurs will allow for better quantification of risk and pricing of credit by investors, in order to mitigate any losses suffered in the event of a bail-in and reduce the need for ex-post compensation. Contingent convertible bonds achieve these ends. More importantly they balance out the competing interests of taxpayers, who want to avoid a public bail-out, and bank creditors, who want to retain a right to their property. The success of CoCos for bailing-in institutions will, however, depend on regulatory intervention to clarify current uncertainties surrounding them in order to encourage their uptake. It is, however, not enough to simply create additional obligations for creditors or favourable instruments. Overall, the implementation of bail-in must be accompanied by better communication, that is, more stringent disclosure requirements for banks, on the risk and returns of their instruments and their liability structures, and, more specificity from regulators on when they will exercise their discretion to activate bail-in. Perfect information from borrowers and regulators could counterbalance the effects of changes to the law. 